\title{
EVALUASI KURIKULUM 2013 \\ DALAM PEMBELAJARAN MATEMATIKA PERMULAAN DI TK NEGERI PEMBINA CIREBON
}

\author{
Ayu Luhanarky \\ Institut Agama Islam Negeri Syekh Nurjati Cirebon \\ E-mail: ayuluha07@gmail.com \\ Maulidya Ulfah \\ Institut Agama Islam Negeri Syekh Nurjati Cirebon \\ E-mail: ulfah@syekhnurjati.ac.id \\ Saifuddin \\ Institut Agama Islam Negeri Syekh Nurjati Cirebon \\ E-mail: saifuddin@syekhnurjati.ac.id
}

Article received: 13 September 2019, Review process: 20 September 2019

Article published: 30 September 2019

\begin{abstract}
The evaluation of curriculum was carried out at TK Negeri Pembina Cirebon especially in Early Mathematics Learning. This type of research is descriptive qualitative. In addition, researchers used the Context, Input, Process, and Product (CIPP) evaluation model. The results of the evaluation found that TK Negeri Pembina Cirebon had used the Curriculum 2013. Permendikbud no. 136, 147 in 2014 and the Directorate book off early childhood education as a reference for preparing the curriculum. The facilities owned are adequate, besides, the comparison of teacher and students at the A class it has been in accordance with the prevailing. Planning for early mathematical activities refers to the Standards for Achieving Child Development Levels, Core Competencies and Basic Competencies. Learning methods in the early mathematical activities are assignments, play, demonstrations, and direct practice. The media used are puzzles, legos, beams and also media made by teachers. Factors supporting in early mathematics learning are teachers who are linear, completing learning plans and adequate facilities and infrastructure, while the inhibiting factors are the psychological readiness of children and parents. The reported child learning outcomes in the form of a description of the growth and development of children and reported results every 6 months.
\end{abstract}

Keywords: Evaluation, Curriculum 2013, Early Mathematics Learning

\section{Abstrak}

Evaluasi kurikulum dilaksanakan di TK Negeri Pembina Cirebon Kabupaten khususnya dalam Pembelajaran Matematika Permulaan. Penelitian ini bertujuan untuk mengevaluasi jalannya 
implementasi kurikulum 2013 PAUD dalam pembelajaran matematika permulaan di TK Negeri Pembina Cirebon ditinjau dari komponen Context, Input, Process, dan Product (CIPP). Hasil evaluasi pada komponen konteks, input, proses dan produk menemukan bahwa TK Negeri Pembina Cirebon telah menggunakan Kurikulum 2013 dan menjadikan Permendikbud no. 136 dan 147 tahun 2014 serta buku Direktorat PAUD sebagai acuan penyusunan kurikulum. Sarana dan prasarana yang dimiliki sudah memadai, selain itu, perbandingan guru dan siswa kelas A sudah sesuai dengan peraturan yang berlaku. Perencanaan kegiatan matematika permulaan mengacu pada Standar Tingkat Pencapaian Perkembangan Anak (STPPA) dan Kompetensi Inti (K-I) serta Kompetensi Dasar (K-D). Metode Pembelajaran pada kegiatan matematika permulaan adalah penugasan, bermain, demonstrasi, dan praktik langsung. Media yang digunakan beraneka ragam mulai puzzle, lego, balok dan juga media buatan guru. Faktor pendukung pembelajaran matematika permulaan adalah guru yang linear, perencanaan pembelajaran yang dan lengkap serta sarana dan prasarana yang memadai, sedangkan faktor penghambat kegiatan matematika permulaan yaitu kesiapan psikologis anak dan orang tua. Hasil belajar anak yang dilaporkan berupa deskripsi pertumbuhan dan perkembangan dan dilaporkan setiap 6 bulan sekali.

Kata Kunci: Evaluasi, Kurikulum 2013, Matematika Permulaan

\section{PENDAHULUAN}

Pendidikan merupakan hal yang penting bagi manusia karena dapat merubah karakter maupun sikapnya. Pendidikan di Indonesia diadakan untuk menunjang kualitas hidup bangsa sebagai mana tercantum Undang-Undang No. 20 Tahun 2003. Menurut UU No. 20 Tahun 2003 tentang Sistem Pendidikan Nasional bahwa, kurikulum merupakan seperangkat rencana dan pengaturan mengenai tujuan, isi, dan bahan pembelajaran serta sebagai pedoman penyelenggaraan kegiatan pembelajaran untuk mencapai tujuan pendidikan tertentu (Eveline \& Hartini, 2011)

Kurikulum 2013 pada jenjang Pendidikan Anak Usia Dini (PAUD) menuntut para pendidik untuk mampu mengembangakan seluruh aspek perkembangan anak sesuai dengan Standar Tingkat Pencapaian Perkembangan Anak (STPPA) yang terdiri dari aspek nilai agama dan moral; fisik motorik; bahasa; kognitif; sosial emosional; dan seni. Namun hal tersebut belum sepenuhnya terealisasi (Permendikbud no. 137, 2014). Menurut Hamid selaku Direktur Jendral Pendidikan Dasar dan Menengah (dikutip dari data Kementerian Pendidikan dan Kebudayaan) bahwa pada tahun 2016 hanya 25\% sekolah yang telah mengimplementasikan Kurikulum 2013. Target pada 2018 adalah 100\% harus telah mengimplementasikan Kurikulum 2013 dari seluruh lembaga PAUD di tiga puluh tiga provinsi di Indonesia, tidak terkecuali Jawa Barat, khususnya Cirebon. 
Dewasa ini sering kali ditemui orang tua yang menuntut pendidik untuk mengajarkan siswa membaca, menulis dan menghitung (calistung). Hal tersebut dapat terlihat dari proses pembelajaran yang belum menggunakan metode dan media yang sesuai dengan kebutuhan anak, terutama pada kegiatan matematika permulaan. Kegiatan matematika permulaan masih dilaksanakan dengan cara mendikte dan memberikan soal di papan tulis. Terdapat banyak faktor yang melatar belakangi kejadiaan tersebut, seperti tuntutan dari orang tua, pendidik yang kurang kreatif dan tidak linear PAUD, minimnya pemahaman pendidik mengenai Kurikulum 2013, serta minimnya ketersediaan media pembelajaran.

Berdasarkan hasil observasi yang dilakukan pada bulan Agustus 2018 bahwa di Kabupaten Cirebon terdapat sekolah yang telah mengimplemetasikan Kurikulum 2013 salah satunya adalah TK Negeri Pembina Cirebon. Peneliti telah menemukan bahwa TK Negeri Pembina Cirebon telah memiliki dokumen Kurikulum 2013 yang lengkap mulai dari data-data sekolah, perencanaan pembelajaran, sarana dan prasarana yang lengkap mulai dari sarana dan prasarana out door maupun sarana dan prasarana in door. Berdasarkan pemaparan di atas, penulis tertarik untuk melakukan penelitian dengan judul Evaluasi terhadap Implementasi Kurikulum 2013 PAUD dalam Pembelajaran Matematika Permulaan di TK Negeri Pembina Cirebon Kabupaten Cirebon.

Penelitian ini merupakan penelitian lanjutan atau pengembangan, mengacu pada penelitian relevan, yaitu: 1) Suharno tahun 2014 berjudul "Implementasi Pembelajaran Berbasis Kurikulum 2013 Pada Mata Pelajaran Biologi Di SMK Negeri 1 Gondang Kabupaten Tulungagung"; 2) Arista Septi Rahmawati tahun 2015 berjudul "Implementaasi Kurikulum 2013 dalam Pembelajaran Matematika pada Siswa Kelas X SMK Muhammadiyah 1 Surkarta Tahun 2014/2015"; 3) Dewi Mahmudah tahun 2016 berjudul "Implementasi Kurikulum 2013 dalam Pembelajaran (Studi Kasus Pembelajaran dengan Pendekatan Saintifik dan Penilaian Otentik di TK ABA Ngampilan Yogyakarta dan TK Budi Mulia Dua Yogyakarta)"; dan 4) Maria Goreti V. Anamara tahun 2014 berjudul "Evaluasi Program Implementasi Standar PAUD”. Penelitian yang akan dilakukan memiliki perbedaan dengan penelitian relevan yakni fokus penelitian yang hanya pada kegiatan matematika permulaan dan juga obyek penelitian yaitu siswa kelas A di TK Negeri Pembina Cirebon.

\section{Model Evaluasi Kurikulum}


Terdapat banyak sekali model evaluasi yang dapat digunakan untuk mengevaluasi kurikulum, seperti measurement, congerance, dan context, input, process and product (CIPP).

Measurement. Model evaluasi measurement yang merupakan model evaluasi tertua dikembangkan oleh R. Thorndike dan R. L. Ebel. Model evaluasi ini menitikberatkan evaluasi pada siswa. Ruang lingkup evaluasi menurut model ini adalah tingkah laku siswa, diantaranya kemampuan hasil belajar, intelegensi dan bakat, minat, sikap, dan juga aspekaspek kepribadian siswa. (Qomari, 2008).

Congruence. Model evaluasi congerance dipelopori oleh Raph W. Tyler, John B. Carrol, dan Lee J. Cronbach yang digunakan untuk melihat kesesuaian (congruence) antara tujuan dengan hasil belajar yang dicapai (Anonim, 2017). Terdapat tiga hal utama yang digambarkan oleh model ini yaitu tujuan pendidikan, pengalaman belajar dan penilaian terhadap hasil belajar. Evaluasi ini pada dasarnya ingin memperoleh gambaran mengenai efektivitas dari sistem pendidikan dalam mencapai tujuan pendidikan itu sendiri (Widiyoko, 2013).

CIPP. Model evaluasi context, input, process and product (CIPP) yang diprakarsai oleh tim peneliti dari Phi Delta Kappa USA dan diketuai oleh Daniel Stufflebeam. Model CIPP memiliki empat fokus yaitu conteks, input, proses dan produk. Menurut Anamara bahwa model CIPP merupakan model evaluasi yang memandang program sebagai sebuah sistem (Anamara, 2014).

Penelitian ini menggunakan model evaluasi context, input, process and product (CIPP). Hal tersebut dikarenakan model evaluasi CIPP dianggap peneliti sebagai model evaluasi yang komprehensif, serta memudahkan peneliti untuk membagi fokus penelitian ke dalam masing-masing komponen yang tersedia dalam model evaluasi context, input, process and product (CIPP).

\section{Konsep Kurikulum di Indonesia}

Menurut UU No. 20 Tahun 2003 tentang Sistem Pendidikan Nasional bahwa, kurikulum merupakan seperangkat rencana dan pengaturan mengenai tujuan, isi, dan bahan pembelajaran serta sebagai pedoman penyelenggaraan kegiatan pembelajaran untuk mencapai tujuan pendidikan tertentu (Eveline \& Hartini, 2011). Menurut B. Othanel smith bahwa kurikulum adalah " a sequence of potential experience is set up in the school for the purpose of 
diciplining children and youth in gruop ways thinking and action” (Suyadi \& Dahlia, 2013). Artinya bahwa kurikulum adalah runtutan dari pengalaman potensial yang terjadi di sekolah yang bertujuan untuk mendisiplinkan anak dalam pembelajaran yang tengah berlangsung. Menurut Hermawan dan Cynthia bahwa kurikulum memiliki peran sebagai pelestari atau penguat dari tujuan pendidikan, membentuk pribadi yang kreatif dan kritis serta sebagai alat untuk mengevaluasi jalannya pendidikan atau disebut juga evaluator (Triwiyanto, 2015). Berdasarkan ketiga pendapat di atas, maka kurikulum memiliki tujuan yang beragam yang pada dasarnya adalah digunakan untuk mencapai tujuan pendidikan itu sendiri.

Kurikulum 2013 merupakan kurikulum terbaru di dunia pendidikan Indonesia yang mengacu pada Peraturan Menteri Pendidikan dan Kebudayaan No. 146 tahun 2014. Standar kompetensi pendidik berdasarkan Kurikulum 2013 ada 4 yaitu 1) kompetensi pedagogik; 2) kompetensi kepribadian; 3) kompetensi profesional; dan 4) kompetensi sosial (Permendikbud no. 146, 2014). Perkembangan anak yang harus dicapai pada dasarnya telah tercantum dalam Kurikulum 2013 yaitu Standar Tingkat Pencapaian Perkembangan Anak, yang disesuaikan dengan usia kelas A (Permendikbud no. 137, 2014).

\section{Pembelajaran Matematika Permulaan di PAUD}

Pembelajaran matematika di PAUD sedikit berbeda dengan di jenjang pendidikan yang lebih tinggi. Pembelajaran harus menggunakan media dan metode yang tepat, dan setiap satuan pendidikan wajib memiliki sarana yang menunjang proses pembelajaran, seperti halnya media pembelajaran. (Manan, Mus'adatul, Fithriyah, \& Nawafilaty, 2017). Berdasarkan hal tersebut, mengacu kepada teori dari Jean Piaget tentang perkembangan kognitif anak tahap praoperasional (2-7 tahun) dimana anak mampu merepresantasikan benda atau kejadian secara simbolik (Winfred, 2012). Sudah seharusnya bahwa pembelajaran matematika mengacu pada teori yang mendukung, seperti halnya menurut Royar bahwa pembelajaran matematika harus berdasarkan teori perkembangan dan konsep yang jelas dan terverifikasi. (Langhorst, Ehlert, \& Fritz, 2013).

\section{Konsep Anak Usia Dini dan Pendidikan Anak Usia Dini (PAUD)}

Menurut Patimah bahwa Pendidikan Anak Usia Dini (PAUD) adalah suatu proses pembinaan tumbuh kembang anak sejak usia 0 sampai 6 tahun yang dilakukan secara menyeluruh, mencakup semua perkembangan anak dengan memberikan stimulasi agar anak 
dapat berkembangan secara optimal (Patimah, 2015). Begitupula menurut Morrison bahwa pendidkan anak usia dini merupakan pendidikan untuk young learners sebelum memasuki jenjang sekolah formal berikutnya yaitu sekolah dasar (Heerden, 2016). Artinya bahwa Pendidikan Anak Usia Dini (PAUD) memiliki peranan yang sangat penting dalam tumbuh kembang anak.

\section{METODOLOGI}

Penelitian yang dilakukan menggunakan pendekatan kualitatif deskriptif. Menurut Sukmadinata bahwa penelitian deskriptif merupakan penelitian yang ditujukan untuk mendeskripsikan peristiwa atau fenomena yang terjadi dalam bentuk aktivitas, karakteristik, hubungan, perubahan, kesamaan dan perbedaannya dengan fenomena lain (Sukmadinata, 2016). Penelitian ini juga menggunakan model evaluasi Context, Input, Process and Product (CIPP). Model CIPP adalah salah satu model evaluasi yang memfokuskan pada bidang context, input, proses dan product atau hasil. Keempat komponen yang disebutkan di atas merupakan sasaran evaluasi, yang tidak lain adalah komponen dari proses sebuah program (Rusman, 2009). Menurut Anamara bahwa model CIPP merupakan model evaluasi yang memandang program sebagai sebuah sistem (Anamara, 2014).

Penelitian ini dilakukan di TK Negeri Pembina Cirebon dengan menggunakan teknik pengumpulan data dalam penelitian ini adalah wawancara, studi dokumen dan observasi. Selain itu, sumber data terbagi menjadi dua yaitu primer dan sekunder. Sumber data primer terdiri dari kepala sekola, guru kelas A1 dan A2, serta kegiatan pembelajaran di TK Negeri Pembina Cirebon, sedangkan data sekunder yaitu buku Kurikulum 2013, perencanaan pembelajaran, dan media yang digunakan dalam pembelajaran. setelah mendapatkan informasi yang diharapkan, peneliti akan menganalisis data menggunakan reduksi data demi didapatkan data yang valid serta menggunakan teknik triangluasi guna menguji keabsahan data yang telah diperoleh.

\section{HASIL DAN PEMBAHASAN}

Penelitian ini menggunakan jenis penilitian kuaitatif deskriptif dengan model evaluasi CIPP, sehingga hasil penelitian akan dijabarkan langsung sesuai dengan masingmasing komponen dalam CIPP yaitu context, input, process dan product.

\section{Komponen Konteks (Context)}


Hasil evaluasi dalam komponen konteks berupa dokumen yang berhubungan dengan Kurikulum 2013. TK Negeri Pembina Cirebon telah menggunakan Kurikulum 2013. Hal tersebut dibuktikan dengan adanya dokumen-dokumen seperti buku Kurikulum 2013, dan dokumen penunjang seperti Peraturan Menteri Pendidikan dan Kebudayaan no. 137 dan no. 146 tahun 2014 serta buku-buku dari Direktorat Pendidikan Anak Usia Dini (PAUD) (Dedi W. Mustofa, 2018).

Tim penyusun kurikulum melibatkan semua pihak yaitu komite, kepala sekolah, guru kelas bahkan guru TU. Kurikulum disuupervisi pada Bulan Oktober dan Maret setiap tahunnya. Penyusunan kurikulum melibatkan semua pihak, agar dapat dipahami secara mendalam mengenai yang tercantum dalam Kurikulum 2013 karena kurikulum sebagai suatu ide dengan kurikulum sebagai kegiatan (proses) merupakan suatu rangkain yang berkeseimbangan, suatu kesatuan yang utuh (Arifin, 2014).

Berdasarkan hasil penelitian yang telah dilakukan oleh peneliti, dapat dikatakan bahwa perencanaan pembelajaran di TK Negeri Pembina Cirebon telah lengkap. Hal tersebut dapat diketahui dari proses pembuatan yang hampir seluruhnya dilakukan pada sebelum tahun pelajaran baru, kecuali Rencana Pelaksanaan Pembelajaran Harian (RPPH) yang dilakukan satu minggu sekali. Perencanaan yang dibuat sangatlah tersusun rapi serta dijilid untuk tiap semester.

Rencana Pelaksanaan Pembelajaran Mingguan (RPPM) telah mencantumkan secara jelas keenam aspek pengembangan. Terdapat enam aspek pengembangan yaitu Nilai Agama dan Moral, Fisik Motorik, Bahasa, Kognitif, Sosial Emosional dan Seni. Kegiatan kognitif yang dilakukan tidak seluruhnya adalah matematika permulaan, namun dalam satu minggu efektif selalu terdapat kegiatan matematika permulaan, baik itu menghubungkan, mengelompokkan, mengurutkan, geometri, mengukur, maunpun mengurutkan pola (Permendikbud no. 137, 2014).

Penyusunan Rencana Pelaksanaan Pembelajaran Mingguan (RPPM) yang berhubungan dengan kegiatan matematika permulaan mengacu pada Standar Tingkat Pencapaian Perkembangan Anak (STPPA). Hal tersebut memiliki tujuan agar pembelajaran dapat dilakukan dengan tepat dan terarah. Standar Tingkat Pencapaian Perkembangan Anak 
(STPPA) menjabarkan tentang capaian perkembangan yang harus dipenuhi oleh siswa sesuai dengan aspek perkembangan dan batasan usia (Permendikbud no. 137, 2014).

Rencana Pelaksanaan Pembelajaran Harian (RPPH) juga disusun sistematis yang mengacu pada Kompetensi Inti (K-I) dan Kompetensi Dasar (K-D) yang telah tersedia. K-I dan K-D yang fokus pada kegiatan matematika permulaan adalah 3.5/4.5 dan 3.6/4.6. Perencanaan penggunaan media juga dilakukan secara matang. Hal tersebut dikarenakan penggunakan media harus dicantumkan dalam Rencana Pelaksanaan Pembelajaran Harian (RPPM). Artinya bahwa media yang digunakan harus telah paten dan tidak diubah lagi ketika telah diketik (Permendikbud no. 146, 2014).

\section{Komponen Input}

Evaluasi pada komponen input memfokuskan pembahasan pada aspek tenaga pendidik dan kependidikan, siswa, serta sarana dan prasarana. Guru dan staf merupakan salah satu komponen dalam bidang pendidikan. Pembelajaran akan berjalan maksimal hanya jika seluruh komponennya saling berkesinambungan, termasuk pada guru dan staff. Menurut maria bahwa guru dan staf termasuk ke dalam komponen input (Anamara, 2014).

Berdasarkan hasil penelitian, hampir seluruh guru atau tenaga pendidik di TK Negeri Pembina Cirebon telah sesuai dengan standar guru PAUD. Jumlah keseluruhan pendidik adalah 10 orang, yang terdiri dari 8 orang guru yang telah s1 PAUD, dan 1 orang guru merupakan sarjana non-PAUD serta 1 orang guru lainnya merupakan lulusan SMK. Tenaga kependidikan yang dimiliki oleh TK Negeri Pembina Cirebon ada 2 orang merupakan lulusan SMK dan sarjana manajemen yaitu memiliki kualifikasi akademik yang mumpuni. Berikut kualifikasi akademik guru 1) memiliki ijazah Diploma empat (D-IV) atau Sarjana (S1) dalam bidang Pendidikan Anak Usia Dini (PAUD) yang diperoleh dari program studi terakreditasi; atau 2) memiliki ijazah diploma empat (D-IV) atau sarjana (S1) kependidikan lain yang relevan atau psikologi yang diperoleh dari program studi terakreditasi dan memiliki sertifikat Pendidikan Profesi Guru (PPG) PAUD dari perguruan tinggi yang terakreditasi. Sedangkan kualifikasi guru pendamping PAUD adalah 1) memiliki ijazah D-II PGTK dari Program Studi terakreditasi; atau 2) memiliki ijazah minimal Sekolah Menengah Atas (SMA) atau sederajat dan memiliki sertifikat pelatihan/pendidikan/kursus PAUD jenjang guru pendamping dari lembaga yang kompeten dan diakui pemerintah. Terakhir adalah kualifikasi guru pendamping 
muda yaitu memiliki ijazah Sekolah Menengah Atas (SMA) atau sederajat, dan memiliki sertifikat pelatihan/pendidikan/kursus PAUD jenjang pengasuh dari lembaga yang kompeten dan diakui pemerintah (Permendikbud no. 137, 2014).

Orang tua juga mempengaruhi keberhasilan siswa. Tidak semua orang tua memahami tentang cara mendidik atau memberikan stimulus yang baik kepada siswa, hal tersebut juga ditentukan oleh lata belakang pendidikan yang dimiliki. Siswa di TK Negeri Pembina Cirebon mayoritas memiliki orang tua yang merupakan lulusan sarjana dan Sekolah Menengah Atas (SMA), namun tetap ada yang merupakan lulusan Sekolah Menengah Pertama (SMP). Menurut Wardhani dan Nilawati bahwa pendidikan orang tua akan berpengaruh terhadap pola pikir dan orientasi pendidikan yang diberikan kepada anaknya. (Novrinda, Kurniah, \& Yulidesni, 2017).

Jumlah siswa di TK Negeri Pembina Cirebon ada 88 siswa. Berdasarkan hal tersebut, jika mengacu pada ketentuan Kurikulum 2013 yang mengharuskan satu guru maksimal mendidik 15 siswa, maka TK Negeri Pembina Cirebon telah memenuhi syarat tersebut, karena dalam satu kelas terdapat dua orang guru, dengan jumlah peserta didik antara 11 hingga 21 siswa. Jumlah guru berbanding dengan jumlah siswa adalah 15 berbanding 1 . Artinya 15 siswa dididik oleh 1 orang guru. Terdapat 35 orang siswa kelas A dengan didampingi oleh 4 guru. Perbandingan antara jumlah siswa dan guru kelas A adalah 8.75: 1 (Dedi W. Mustofa, 2018).

Penunjang dalam pembelajaran juga merupakan hal yang perlu diperhitungkan, dalam hal ini adalah sarana dan prasarana. Sarana prasarana yang ada di TK Negeri Pembina Cirebon cukup baik, terlihat pada beberapa hal seperti gedung sekolah, luas tanah, dan arena bermain telah menunjukkan bahwa sekolah ini telah memenuhi syarat, dimana luas tanah yang dibutuhkan untuk mendirikan gedung TK Negeri Pembina jauh lebih besar melebihi standar yang ada. Setiap siswa diharuskan minimal memiliki area seluas $3 \mathrm{~m}^{2}$, begitupula di TK Negeri Pembina Cirebon yang memiliki 88 siswa dengan hanya 35 siswa kelas A, maka luas yang dibutuhkan adalah $284 \mathrm{~m}^{2}$, atau minimal $300 \mathrm{~m}^{2}$ untuk mendirikan TK dan pada kenyataanya luas yang dimiliki jauh melebihi dari ketentuan yaitu $2.200 \mathrm{~m}^{2}$ (Permendikbud no. 137, 2014). 
Pengadaan sarana in door yang mendukung proses Pendidikan Anak Usia Dini (PAUD) telah memadai, seperti Alat Peraga Edukatif (APE) telah sesuai dengan bidang pengembangan siswa, bahkan ditata dengan rapi sesuai dengan kegunaannya, seperti penataan area khusus balok, masak-masakan, matematika, sains, seni, bahasa fisik dan motorik. TK Negeri Pembina Cirebon juga telah memiliki ruang kepala sekolah, ruang guru, UKS, ruang bermain dan tempat sampah yang tertutup dan dipisahkan antara organik dan non-organik diberapa sudut sekolah. Selain itu hampir setiap sudut halaman sekolah memiliki Alat Permainan Edukatif (APE) out door untuk melatih motorik kasar siswa seperti alat panjat, peluncur, jungkat jungkit, ayunan, bak pasir dan alat putaran mini, yang berjumlah cukup banyak sehingga membuat siswa nyaman berada disekolah. Hal tersebut dapat menjadi keunggulan tersendiri bagi TK Negeri Pembina Cirebon, karena ketersediaan Alat Peraga Edukatif (APE) yang sangat memadai.

\section{Komponen Proses (Process)}

Komponen proses dalam hal ini berkaitan dengan pelaksanaan, faktor yang mendukung dan menghambat dalam pembelajaran khususnya yang berkaitan dengan matematika permulaan di TK Negeri Pembina Cirebon serta berdasarkan komponen proses pada hasil penelitian.

Pembelajaran matematika permulaan yang dilakukan oleh TK Negeri Pembina Cirebon beraneka ragam yaitu mengelompokkan benda berdasarkan ukuran, membentuk gambar segitiga menjadi payung (geometri), membuat awan dari bentuk lingkaran (geometri), meniru gambar segitiga (geometri), mengurutkan pola petir, hujan, banjir (pola), dan menjiplak angka 7 (konsep angka). Begitu pula menurut Coughin dalam bahwa pemahaman dasar siswa mengenai matematika permulaan adalah sebagai berikut: 1) korespondensi satu satu; 2) membilang dan menghitung; 3) mengurutkan; 4) kalkulasi; 5) klasifikasi; 6) pengukuran; 7) perbandingan; 8) geometri; dan 9) pola. Artinya bahwa kegiatan matematika permulaan yang dilakukan di TK Negeri Pembina Cirebon telah dengan jenis-jenis kegiatan matematika permulaan yang seharusnya (Handayani, 2019).

Pelaksanaan pembelajaran khususnya yang berhubungan dengan matematika permulaan di TK Negeri Pembina Cirebon umumnya menggunakan metode penugasan. Meski begitu, namun terdapat metode lain yang digunakan dalam pembelajaran matematika 
permulaan seperti demonstrasi, bermain, dan membuat karya. Metode-metode tersebut saling berhubungan dan melengkapi. Penerapan metode tersebut sangat sederhana, yaitu memanggil siswa untuk mengerjakan tugas dengan diawasi oleh guru dan atau siswa mengerjakan tugas tersebut secara kelompok dengan teman-temanya. Ketika mengerjakan tugas dengan diawasi oleh guru, hal tersebut guna memperdalam dan memperjelas informasi yang akan diberikan kepada siswa agar tidak melenceng dan salah arah. Penggunaan metode pembelajaran sangat dibutuhkan karena metode dapat mempengaruhi pembelajaran itu sendiri. Metode pembelajaran adalah cara sistematis yang dirancang oleh guru untuk mempengaruhi siswa dalam mencapai tujuan pembelajaran (Samiudin, 2016).

Selain metode, TK Negeri Pembina Cirebon juga menggunakan sebuah model pembelajaran, yaitu model kelompok dengan pengaman. Kelompok dengan pengaman artinya bahwa pembelajaran menggunakan model kelompok, lalu dari sela-sela kegiatan inti atau jika siswa telah menyelesaikan seluruh tugas, siswa diperbolehkan untuk bermain sesuai dengan alat permainan yang ditentukan oleh pendidik, misalnya adalah puzzle atau balok. Model Pembelajaran yang digunakan sesuai dengan salah satu ketentuan Peraturan Menteri Pendidikan dan Kebudayaan yaitu model kelompok dengan pengaman. Hal tersebut menguntungkan bagi siswa, karena setelah selesai melakukan kegiatan, maka dapat bermain bebas dan me-refresh otak siswa agar tidak bosan dan terlalu pusing dengan beragam kegiatan. (Permendikbud no. 146, 2014).

Begitupun dengan media pembelajaran, media yang digunakan di TK Negeri Pembina Cirebon umumnya adalah buatan guru. seperti gambar yang diprint dan dilaminating (flash card), gambar segitiga dan lingkaran yang dipotong-potong oleh guru serta pemanfaatan Lembar Kerja Anak (LKA). Media yang digunakan tentunya sesuai dengan tema kegiatan dan juga perkembangan anak. Hal tersebut sesuai dengan pendapat Winarno bahwa terdapat banyak permainan untuk mengembangkan kecerdasan matematis, seperti kartu pintar, berburu harta karun, flash card, boox number, menebak uang, memahami bentuk, dan lain sebagainya (Winarno, 2011). Begitupla menurut Shofyatun bahwa penggunaan Alat Permainan Edukatif (APE) yang sesuai dengan tingkat perkembangan anak akan membantu guru dalam mengembangkan seluruh kemampuan dasar anak. (Hasanah, 2019). 
Hal yang harus diperhatikan dalam pembalajaran selain pembelajaran itu sendiri juga terdapat faktor-faktor yang menunjang dan menghambat dalam pencapaian tujuan pembelajaran. Pembelajaran akan berhasil dan memiliki hasil yang maksimal, pasti karena di dukung oleh beberapa faktor, faktor pendukung dalam pembelajaran di TK Negeri Pembina Cirebon adalah:

Guru yang Linear. Guru merupakan salah satu sumber dalam proses pembelajaran. Guru diharuskan memiliki 4 kompetensi, yaitu pedagogik, sosial, professional dan kepribadian. Hal tersebut dapat menggambarkan betapa pentingnya posisi seorang guru dalam pembelajaran (Rusman, 2010). TK Negeri Pembina Cirebon memilik 8 guru kelas yang linear dan 2 guru pendamping non-liner. Guru yang linear setidaknya dapat dikatakan memiliki 2 kompetensi sekaligus yaitu kompetensi pedagogik dan professional. Dikatakan demikian karena guru yang linear dipastikan telah mendapatkan materi pembelajaran tentang pengelolaan pembelajaran, membuat perencanaan, melakukan evaluasi, mengetahui karakteristik siswa, memiliki pengetahuan tentang bidang studi dan kurikulum serta dapat memahami macam-macam metode, model, strategi dan juga pendekatan dalam pembelajaran. Peran guru begitu penting, karena guru juga berperan sebagai sumber belajar. Menurut sanjaya bahwa guru menjadi media yang dapat memengaruhi belajar siswa, yang berarti media menitikberatkan pada proses dan siswa itu sendiri. (Sanjaya, 2012).

Perencanaan Pembelajaran yang Lengkap dan Matang. Perencanaan merupakan serangkaian proses dan dokumen yang tidak dapat dipisahkan dari kegiatan pembelajara. Menurut Majid bahwa perencanaan merupakan proses penyusunan materi ajar, penggunaan media, metode, pendekatan dan juga penilaian untuk mencapai tujuan tertentu (Fitri, Saparahayuningsih, \& Agustriana, 2017). TK Negeri Pembina Cirebon telah memiliki perencanaan yang lengkap yang terdiri dari program kerja tahunan, program semester, Rencana Pelaksanaan Pembelajaran Mingguan (RPPM) dan juga Rencana Pelaksaan Pembelajaran Harian (RPPH). Pentingnya perencanaan yang lengkap dan matang adalah demi tercapainya tujuan pembelajaran.

Sarana dan Prasarana yang Memadai. Pentingnya sarana dan prasarana dalam menunjang proses pembelajaran diungkapkan oleh Hallak yang mengatakan bahwa sarana dan prasarana diidentifikasi sebagai faktor yang sangat memberi andil besar terhadap prestasi 
akademik siswa (Jannah \& Sontani, 2018). Berdasarkan pentingnya sarana dan prasarana tersebut, TK Negeri Pembina Cirebon memiliki media pembelajaran atau Alat Permainan Edukatif (APE) yang sangat beragam. Pembelajaran juga selalu menggunakan media pembelajaran tidak terkecuali dalam kegiatan matematika permulaan, sehingga siswa dapat lebih mudah menyerap informasi atau pengetahuan baru. Selain itu, fasilitas gedung, toilet, perpustakaan, Alat Peraga Edukatif (APE) out door, aula, halaman sekolah dan tempat mencuci tangan yang sangat memadai untuk mendukung tercapainya tujuan pembelajaran.

Selain faktor yang mendukung, terdapat pula yang dapat menghambat dalam pembelajaran. berikut adalah faktor yang menghambat dalam pembelajaran di TK Negeri Pembina Cirebon:

Kesiapan Psikologis Siswa. Kesiapan psikologis yang dimaksud berkaitan erat dengan jenjang usia. Usia untuk kelompok A adalah dari 4-5 tahun. Penemuan kali ini adalah siswa tersebut memiliki jenjang usia yang termasuk ke dalam kelompok A, namun paling muda diantara teman lain, sehingga kerap kali lambat dalam menerima pengetahuan. Setiap siswa memiliki karakteristik yang unik dan berbeda satu sama lain, dan sedang dalam tahap perkembangan segala aspek pengembangannya. Artinya bahwa meskipun usia siswa sama namun belum tentu sama-sama memiliki kesiapan psikologis dalam belajar (Novitawati, 2013). Begitu pula menurut Suyono bahwa pemberian pembelajaran harus disesuaikan dengan skema perkembangan seseorang, karena setiap siswa memiliki skema perkembangan yang berbeda. Hal tersebut terkait dengan teori dari Cronbach yaitu readiness atau kesiapan belajar. Readiness yang dimaksud adalah ketika siswa telah berada dalam kondisi yang membuatnya siap untuk memberikan respon atau timbal balik dari proses pembelajaran dengan cara tertentu (Srinahyani, 2017).

Orang Tua. Orang tua adalah guru utama dan pertama bagi anak. Anak mendapatkan materi atau informasi baru bukan hanya disekolah melainkan juga dirumah. Menurut Mukhtar dkk bahwa pendidikan di sekolah hanya mendapat porsi $20 \%$ dari total pendidikan yang di peroleh anak. Ki Hajar Dewantara juga mengemukakan bahwa anak menghabiskan waktunya sebesar $80 \%$ bersama keluarga, sehingga pendidikan yang utama dan pertama bagi anak adalah keluarga. Artinya bahwa orang tua harus mampu menjadi guru yang baik bagi anak, tidak hanya menyerahkan pendidikan anak kepada pihak sekolah. Kerap kali orang tua hanya 
mempercayakan anaknya kepada pihak sekolah tanpa memberikan stimulasi tambahan ketika di rumah. Hal tersebut yang kerap kali menjadikan orang tua sebagai faktor penghambat bagi perkembangan anak (Qadafi, 2019). Menurut Wardhani dan Nilawati bahwa pendidikan orang tua akan berpengaruh terhadap pola pikir dan orientasi pendidikan yang diberikan kepada anaknya. Semakin tinggi pendidikan yang dimiliki oleh orang tua maka akan semakin memperluas pola berpikir dalam mendidik anak (Novrinda et al., 2017).

\section{Komponen Hasil (Product)}

Salah satu bagian terpenting dalam pembelajaran adalah evaluasi. Evaluasi inilah yang akan memperlihatkan bagaimana progress dari perkembangan siswa, baik itu setiap hari, minggu, maupun semester. TK Negeri Pembina Cirebon memiliki beberapa catatan hasil evaluasi siswa, yaitu catatan anekdot, percakapan, hasil karya, unjuk kerja, observasi dan catatan hasil penugasan. Adapula catatan harian, mingguan dan semester. Catatan hasil evaluasi belajar tersebut termasuk ke dalam penilaian autentik. Penilaian autentik adalah penilaian proses dan hasil belajar untuk mengukur tingkat pencapaian kompetensi sikap (spiritual dan sosial), pengetahuan dan keterampilan yang dilakukan secara berkesinambungan. Penilaian tidak hanya mengukur apa yang diketahui oleh anak, tetapi lebih menekankan mengukur apa yang dapat dilakukan oleh anak (Permendikbud no. 146, 2014).

Guru memberikan penilaian berdasarkan apa yang siswa pelajari dan tugas yang diberikan, penilaian juga bersifat berkepanjangan dari mulai catatan harian, mingguan hingga semester dan kemudian dilaporkan kepada orang tua dalam bentuk raport, metode pencatatan yang digunakanpun beragam dari mulai catatan anekdot, penugasan, unjuk kerja, percakapan, hasil karya hingga observasi. (Zahro, 2015). Evaluasi pada komponen ini memperlihatkan bahwa laporan hasil belajar anak dilaporkan sesuai dengan Standar Tingkat Pencapaian Perkembangan Anak (STPPA) yang diatur dalam standar PAUD. Artinya setiap aspek pengembangan anak dijelaskan tingkat ketercapaiannya.

Penilaian ditulis menggunakan deskripsi pertumbuhan fisik dan perkembangan kompetensi sikap, pengetahuan, dan keterampilan anak yang dilaporkan kepada orang tua dilengkapi dengan lampiran hasil portofolio, sehingga hal tersebut bisa dikatakan adil. Jika penulisan penilaian hanya menggunakan ceklis, atau angka saja maka artinya setiap siswa perkembangannya disamakan dalam artian jika siswa mendapat MB, maka semua siswa yang 
mendapatkan MB perkembangannya sama, namun jika menggunakan deskripsi juga maka dapat dijadikan pembeda bagi setiap siswa, karena memang setiap siswa pasti berbeda. Bahkan tidak hanya deksripsi dan ceklis, namun juga di beberapa kejadian disertakan bukti foto, namun tidak disemua kejadian. Teknik pelaporan dilakukan dengan cara bertatap muka dengan orang tua untuk menjelaskan hasil penilaian anak. Pelaporan secara tertulis diberikan kepada orang tua minimal sekali untuk setiap 6 bulan, sedangkan pelaporan secara lisan dapat diberikan sesuai kebutuhan. Buku laporan penilaian perkembangan anak telah menggunakan format yang sesuai Peraturan Menteri Pendidikan dan Kebudayaan (Permendikbud no. 146, 2014).

\section{SIMPULAN}

Berdasarkan hasil evaluasi menggunakan model Context, Input, Process dan Product (CIPP), didapatkan bahwa TK Negeri Pembina Sumber telah menggunakan Kurikulum 2013 dan menjadikan Permendikbud no. 136 dan 147 tahun 2014 serta buku Direktorat PAUD sebagai acuan penyusunan kurikulum. Perencanaan pembelajaran matematika permulaan di TK Negeri Pembina Sumber telah dilaksanakan dengan baik dan lengkap, terdiri dari program kerja tahunan, program semester dan Rencana Pelaksanaan Pembelajaran Mingguan (RPPM) dibuat pada awal tahun pelajaran, sedangkan Rencana Pelaksanaan Pembelajaran Harian (RPPH) dibuat setiap satu minggu sekali. Kegiatan matematika permulaan tidak selalu diadakan setiap hari, namun selalu ada di setiap minggu efektif. Pelaksanaan pembelajaran di TK Negeri Pembina Sumber menggunakan model kelompok dengan pengaman, pembelajaran menggunakan metode penugasan, demonstrasi, bermain, praktik langsung, dan percakapan. Media yang digunakan dalam pembelajaran matematika permulaan sangat beragam, seperti lego, puzzle, Lembar Kerja Anak (LKA) dan juga media buatan guru. Faktor pendukung pembelajaran matematika permulaan di TK Negeri Pembina Sumber yaitu 1) guru yang linear; 2) perencanaan yang lengkap; dan 3) sarana dan prasarana yang memadai; sedangkan faktor penghambat dalam pembelajaran matematika permulaan adalah 1) kesiapan psikologis anak; dan 2) orang tua. Jenis penilaian yang digunakan adalah BB, MB, BSH dan BSB, sedangkan catatan hasil evaluasi belajar siswa adalah catatan anekdot, percakapan, hasil karya, unjuk kerja, observasi dan catatan hasil penugasan. Hasil belajar anak yang dilaporkan berupa deskripsi pertumbuhan dan perkembangan anak dilengkapi dengan lampiran hasil 
portofolio. Teknik pelaporan dilakukan dengan cara bertatap muka dengan orang tua untuk menjelaskan hasil penilaian anak. Pelaporan secara tertulis diberikan kepada orang tua minimal sekali untuk setiap 6 bulan, sedangkan pelaporan secara lisan dapat diberikan sesuai kebutuhan.

\section{DAFTAR PUSTAKA}

Anamara, M. G. V. (2014). Evaluasi Program Implementasi Standar Paud. Jurnal Pendidikan Anak Usia Dini, 8, 291-304.

Anonim. (2017). Implementasi Model Evaluasi Kesesuaian (Congruence Model) Terhadap Pemahaman Dan Perilaku Siswa Pada Mata Pelajaran Aqidah Akhlak. Repositori STAIN Kudus.

Arifin, Z. (2014). Penelitian Pendidikan (Metode dan Paradigma). Bandung: Remaja Rosdakarya.

Dedi W. Mustofa. (2018). Pengelolaan Kelas Pendidikan Anak Usia Dini. Jakarta: Direktorat Pembinaan Pendidikan Anak Usia Dini.

Dedi W. Mustofa. (2018). Pengembangan Tema Pembelajaran Pendidikan Anak Usia Dini. Jakarta: Direktorat Pembinaan Pendidikan Anak Usia Dini.

Eveline, \& Hartini. (2011). Teori Belajar dan Pembelajaran. Bogor: Ghalia Indonesia.

Fitri, A. E., Saparahayuningsih, S., \& Agustriana, N. (2017). Perencanaan Pembelajaran Kurikulum 2013 Pendidikan Anak Usia Dini (Penelitian Deskriptif Kuantitatif di PAUD IT Auladuna Kota Bengkulu). Potensia, PG-PAUD FKIP UNIB, Vol. 2.

Handayani, O. D. (2019). Pembelajaran Matematika Permulaan Melalui Kewirausahaan dan Aktivitas Bercocok Tanam Pada Anak Usia Dini. UPGRIS.

Hasanah, U. (2019). Penggunaan Alat Permainan Edukatif (APE) pada Taman Kanak-Kanak di Kota Metro Lampung. Awlady: Jurnal Pendidikan Anak, Vol. 5 No.

Heerden, J. Van. (2016). Quality in South Arican Early Learning centers: Mother's and Teacher's Views and Understanding. South African Journal o Childhood Education.

Jannah, S. N., \& Sontani, U. T. (2018). Sarana dan Prasarana Pembelajaran Sebagai Faktor Determinan Terhadap Motivasi Belajar Siswa. Jurnal Pendidikan Manajemen Perkantoran, Vol. 3. 
Langhorst, P., Ehlert, A., \& Fritz, A. (2013). Realising Pre-School Mathematical Education a development- Oriented Math Programme with Special Consideretion of Phonologiccal Language Processing Aspect. Sun Media Metro: South African Journal of Childhood Education, 1 .

Manan, A., Mus'adatul, Fithriyah, \& Nawafilaty, T. (2017). Pengaruh Media Dadu Huruf terhadap Kemampuan Mengenal Huruf Hijaiyyah pada Kelompok B di TK Kecamatan Glagah-Lamongan. Awlady, 8.

Novitawati. (2013). Kesiapan Sekolah Anak Taman Kanak-Kanak Berbasis Model Pembelajaran Sentra. Jurnal Pendidikan Anak Usia Dini, Vol.7.

Novrinda, Kurniah, N., \& Yulidesni. (2017). Peran Orang Tua dalam Pendidikan Anak Usia Dini Ditinjau dari Latar Belakang Pendidikannya. Jurnal Potensia, Vol. 2.

Patimah. (2015). Integrasi Pendidikan Moral dan Pengembangan Kemampuan Kognitif Anak pada Jenjang Pendidikan Anak Usia Dini. Awlady: Jurnal Pendidikan Anak, Vol. 1 No.

Permendikbud no. 137. (2014). Standar Nasional Pendidikan Anak Usia Dini.

Permendikbud no. 146. (2014). Kurikulum Pendidikan Anak Usia Dini.

Qadafi, M. (2019). Kolaborasi Guru dan Orang Tua dalam Mengembangkan Aspek Moral Agama Anak Usia DIni. Awlady: Jurnal Pendidikan Anak, Vol. 5 No.

Qomari, R. (2008). Model Evaluasi Pendidikan. INSANI, 13.

Rusman. (2009). Manajemen Kurikulum. Jakarta: PT Raja Grafindo Persada.

Rusman. (2010). Model-Model Pembelajaran Mengembangkan Profesionalisme Guru. Jakarta: PT Raja Grafindo Persada.

Samiudin. (2016). Peran Metode untuk Mencapai Tujuan Pembelajaran. Jurnal Studi Islam, Vol. 11 No.

Sanjaya, W. (2012). Media Komunikasi Pembelajaran. Jakarta: Kencana.

Srinahyani. (2017). Kesiapan Bersekolah Anak Taman Kanak-Kanak Kelompok B Ditinjau Dari Lembaga Pendidikan dan Tingkat Pendidikan Orang Tua. Jurnal Unimed, Vol. 7 No.

Sukmadinata, N. (2016). Metode Penelitian Pendidikan. Bandung: PT Remaja Rosdakarya.

Suyadi, \& Dahlia. (2013). Implementasi dan Orientasi Kurikulum PAUD 2013. Bandung: PT Remaja Rosdakarya. 
Triwiyanto, T. (2015). Manajemen Kurikulum dan Pembelajaran. Jakarta: PT Bumi Aksara.

Widiyoko, E. P. (2013). Evaluasi Program Pembelajaran (Panduan Praktis bagi Pendidik dan Calon Pendidik). Yogyakarta: Pustaka Pelajar.

Winarno. (2011). Membantu Anak Belajar Matematika. Jakarta: Oryza.

Winfred. (2012). Theories Of Learning (Teori-Teori Pembelajaran Konsepsi, Komparasi dan Signifikansi). Bandung: Nusa Media. 